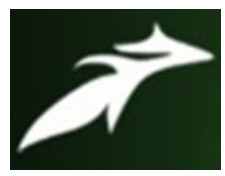

Repalle Yuvaraju et al, International Journal of Advances in Agricultural Science and Technology,

Vol.7 Issue.12, December-2020, pg. 9-14

ISSN: 2348-1358

Impact Factor: 6.057

NAAS Rating: 3.77

\title{
Constraints and Suggestions Encountered by the Gram Panchayat Members in Performing their Roles in Agricultural Development in Kurnool District of Andhra Pradesh
}

\author{
${ }^{1}$ Repalle Yuvaraju; ${ }^{2}$ Dr. Jahanara; ${ }^{3}$ Dr. D.K.Bose \\ ${ }^{1}$ Author M.Sc.(Ag) Department of Agriculture Extension and Communication \\ ${ }^{2}$ HOD Department of Agriculture Extension and Communication \\ ${ }^{3}$ Associate Professor Agriculture Extension and Communication \\ Sam Higginbottom University of Agriculture Technology and Sciences, Prayagraj, UP.
}

DOI: 10.47856/ijaast.2020.v07i12.002

\begin{abstract}
The study was conducted in role performance of gram panchayat members in agricultural development in Kurnool district of Andhra Pradesh. The analysis showed that the most important constraint according to the gram panchayat members were 'Ground water level going down day by day' secured $1^{\text {st }}$ rank with Mean Percent Score of 86.99, followed by 'Unavailability of improved seeds and other inputs in the village itself' (85.32), 'Lack of training' (83.64), 'Due to personal work there is less time for agricultural developmental work' (80.53), 'Low support prices for cereal crops' (76.46), 'Lack of finance' (74.64), 'Noninvolvement of women members in panchayat meetings and disregarding the view-point of those who attend' (72.30), 'Lack of co-operation from officials in providing loan to the poor people' (68.79).
\end{abstract}

Keywords: Gram panchayat, constraints and suggestions.

\section{Introduction}

Panchayat raj system is an age old concept of local self government or democracy practiced in the history of civilization in India. Gram Panchayat are primary basic unit of Panchayat raj administration. It was first introduced in1959 following the Balwant Rai Metha committee report a three tier structure of local self government consisting of gram panchayat at the village level, taluka Panchayat samiti at the tahils level and zilla parshid at the district level. Accordingly, Panchayat raj system has been in operation in the country. Gram Panchayat is most important basic institution for village development. It plays an 


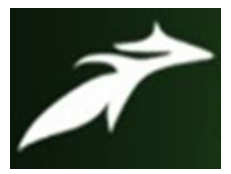

Repalle Yuvaraju et al, International Journal of Advances in Agricultural Science and Technology,

Vol.7 Issue.12, December-2020, pg. 9-14

ISSN: 2348-1358

Impact Factor: 6.057

NAAS Rating: 3.77

important role at the village level in proper functioning of the panchayat raj system. It is the most potential school of social and political training for the rural masses. Gram panchayat is grass root organization of panchayat raj system.

The Panchayat raj community development programmae has now become the programmae of the people, for the people, by the people. With this introduction of panchayat raj, A new era in rural development has started in the country. Elected representatives of people got some important powers and functions to play a significant role and shoulder the responsibility.

Elected members of gram Panchayat are formal leaders and accepted by the local people. Gram members play important role in village development activities. India's ever increasing population has to be fed by increased food production. Improved agriculture production technologies should be employed or adopted in rural areas of farming. Government runs many agriculture development programmes to enhance the growth in agriculture production. These programmes should reach to the bunds of the farmers field in villages. That's why to spread and adopt the agriculture development programmes they should firstly be adopted by gram panchayat members the ultimate leaders of villagers so that villagers follow their leaders.

Gram Panchayat members as the representative of the people are expected to know the details of the various agriculture development programmes under taken by government authority. This enables them gram panchayat members. In motivating and guiding their followers particularly in agricultural development. Gram pancahayat is formed by election procedure. The adult citizen voters elect their leaders as members of gram panchayat from the ward by observing formal voting procedure. Then the members their chief leader known as sarpanch. Every member has been assigned a portfolio of gram panchayat work. Gram pancahayat secretary is official man and he is known as gram sevak. He assists the work of sarpanch and keeps records and documentation. The sarpanch is directly elected by voters of the whole village.

Gram panchayat is the most important tier of the panchayat raj because it is a pillar of panchayat raj system due to which people at grass root or villagers can develop 


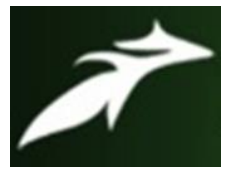

Repalle Yuvaraju et al, International Journal of Advances in Agricultural Science and Technology,

Vol.7 Issue.12, December-2020, pg. 9-14

ISSN: 2348-1358

Impact Factor: 6.057

NAAS Rating: 3.77

themselves and develop leadership of country. It has been universally realized and accepted that statutory organization in each village, enabling the villagers to look after the administration of their own affairs, is of primary importance in building up of democratic self government. it is the time, the gram panchayats are made aware of the need for a community action especially in the implementation of various schemes related to agricultural production and other schemes related to sanitation, construction of houses and roads, etc. it is highly desirable to provide nuclei of the energy, enthusiasm and initiative in the form of vigorous and dynamic panchayats.

\section{Methodology:}

An Descriptive research design was followed. The study was conducted in Kurnool district of Andhra Pradesh state during the year, 2019-20. Kurnool district of Andhra Pradesh was selected, out of 54 mandals, Two mandals is selected purposively and ten villages were selected from each mandal for the study. Respondents were selected from the village by following proportionate random sampling method. Thus, 120 gram panchayat members constituted as sample for the study. Data were collected by pre-tested schedule followed by personal interview method. For the purpose of statistical analysis of the coded data, appropriate statistical tools were used viz., frequency and percentages and ranking.

\section{Results and Discussion:}

Constraints faced by Gram Panchayat Members during Agriculture Development Programmes

$\mathrm{N}=120$ (multiple response)

\begin{tabular}{|l|l|c|c|}
\hline \multicolumn{1}{|c|}{$\begin{array}{c}\text { S. } \\
\text { No. }\end{array}$} & \multicolumn{2}{|c|}{ Constraints } & \multicolumn{2}{c|}{ Response } \\
\cline { 3 - 4 } & & Number & Per cent \\
\hline 1 & Lack of finance & 100 & 83.64 \\
\hline 2 & Non co-operation among the GPMs & 75 & 62.34 \\
\hline
\end{tabular}




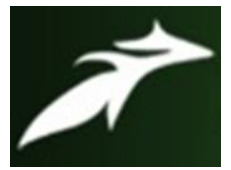

Repalle Yuvaraju et al, International Journal of Advances in Agricultural Science and Technology, Vol.7 Issue.12, December-2020, pg. 9-14

ISSN: 2348-1358

Impact Factor: 6.057

NAAS Rating: 3.77

\begin{tabular}{|l|l|c|c|}
\hline 3 & $\begin{array}{l}\text { Agricultural departmental staff is not interested in implementing } \\
\text { various schemes in villages }\end{array}$ & 74 & 61.05 \\
\hline 4 & $\begin{array}{l}\text { Language in the information booklet is difficult to understand by } \\
\text { people }\end{array}$ & 77 & 63.81 \\
\hline 5 & $\begin{array}{l}\text { Agriculture departmental staff cannot provides information due } \\
\text { to inadequate staff }\end{array}$ & 70 & 58.20 \\
\hline 6 & Lack of encouragement of Progressive farmers & 79 & 65.68 \\
\hline 7 & Farmers not believe in new technology faster & 82 & 68.32 \\
\hline 8 & No proper guidance from officials & 80 & 65.98 \\
\hline 9 & Less publicity about agricultural development programmes & 68 & 56.84 \\
\hline 10 & $\begin{array}{l}\text { Illiteracy of gram panchayat members leads to various } \\
\text { difficulties in administrative works }\end{array}$ & 82 & 68.34 \\
\hline 11 & Short supply of electricity for irrigation & 70 & 58.54 \\
\hline 12 & Low support prices for cereal crops & 70 & 58.62 \\
\hline 13 & $\begin{array}{l}\text { Lack of co-operation from officials in providing loan to the poor } \\
\text { people }\end{array}$ & & \\
\hline
\end{tabular}

From table it can be understood that lack of finance was the most problematic constraint (83.04\%), followed by short supply of electricity $(68.34 \%)$, no proper guidance from officials (65.98\%), lack of encouragement of progressive farmers (65.68\%), language in the information booklet is difficult to understand by people (63.81\%), non-co-operation from the GPM's (62.34\%), illiteracy of gram panchayat members leads to various difficulties in administrative works $(62.25 \%)$, agricultural departmental staff is not interested in implementing various schemes in the village (61.05\%), lack of co-operation from officials in providing loan to the poor people $(58.62 \%)$, low support prices for cereal crops (58.54\%), agriculture departmental staff cannot provides information to adequate staff (58.20\%), less publicity about agricultural 


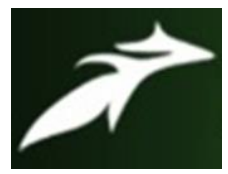

Repalle Yuvaraju et al, International Journal of Advances in Agricultural Science and Technology,

Vol.7 Issue.12, December-2020, pg. 9-14

ISSN: 2348-1358

Impact Factor: 6.057

NAAS Rating: 3.77

development programmes (56.84\%) secured the following ranks simultaneously. Similar findings were reported by Suradkar (2005), Dedun et.al., (2016) and Vinod Kumwat (2018).

\section{Suggestions for Future Research:}

1. As the study was localized to only two blocks, hence valid generalization cannot be drawn. Therefore, similar studies may also be conducted at several locations to draw comparison and generalization from the study.

2. The studies on the same lines should be conducted across states and at the national level and with large samples.

3. As the study was academic in nature, the independent and dependent variables were limited in the present study. Further studies may be conducted with more and different independent and dependent variables.

4. The present study is based on recall data. Thus the future studies may be done by experimental research or participant observation to base the study on more authentic and accurate data.

\section{Conclusion:}

It has been concluded that the most important constraint according to the gram panchayat members were lack of finance was the most problematic constraint $(83.04 \%)$, followed by short supply of electricity (68.34\%), no proper guidance from officials (65.98\%), lack of encouragement of progressive farmers $(65.68 \%)$, language in the information booklet is difficult to understand by people (63.81\%), non-co-operation from the GPM's $(62.34 \%)$, illiteracy of gram panchayat members leads to various difficulties in administrative works (62.25\%), agricultural departmental staff is not interested in implementing various schemes in the village $(61.05 \%)$, lack of co-operation from officials in providing loan to the poor people $(58.62 \%)$, low support prices for cereal crops $(58.54 \%)$, agriculture departmental staff cannot provides 


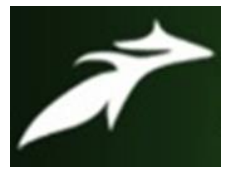

Repalle Yuvaraju et al, International Journal of Advances in Agricultural Science and Technology,

Vol.7 Issue.12, December-2020, pg. 9-14

ISSN: 2348-1358

Impact Factor: 6.057

NAAS Rating: 3.77

information to adequate staff $(58.20 \%)$, less publicity about agricultural development programmes $(56.84 \%)$.

\section{References}

[1]. Deshmukh, J.M.; Kshatriya, A.M. and Shinde, A.V. 2013 Constraints faced by women member of Gram Panchayat. Agric. Update, 8 (1\&2).

[2]. Dedun, V.S.; Naik, R.M. and Gamit, P.S. 2016 Constraints Faced by GramPanchayat Members in Performing their Role for Village Development. International J.Agric. Sci., 3ISSN: 0975-3710 \& EISSN: 0975-9107,(8), (21).

[3]. Paul, S. and Chakravarty, R. 2009 Constraints in Role Performance of Gram Panchayat in Agriculture, Ind.Res. J. Ext. Edu. 9 (3)

[4]. Vinod Kumwat. 2018. Role of Gram Panchayat Members in Agriculture Development of Jaipur District, Rajasthan. M.Sc. (Ag.) Thesis. Sri Karan Narendra Agriculture University, Jobner.

[5]. Sidhu, K. 2015 Profile of Women Panchayat Members and Awareness ofRoles and Responsibilities. Global J. Engg. Sci. \& Soc. Sci.Studies, Available online at www.gjesss.co. (01), (06), 5 ISSN: 2394-3084.

[6]. Sharma. V. 2008 A study on role performance of village panchayat leaders in Burhar block of Shahdol district, M.P. M.Sc. (Ag.) Thesis, JNKVV,Jabalpur.

[7]. Tiwari, P.K. 2007 A study of role performance of panchayat leaders in Rewablock of district Rewa (M.P.). M.Sc. (Ag.) thesis J.N.K.V.V., Jabalpur.

[8]. Pushpakumari, C.S. 2012 Extent of participation of women members inMandal Panchayat activities - An exploratory study. M.Sc. (Agri.). Thesis, UAS, Bangalore.

[9]. Desh pande, A.R.; Soni, M.C. and Shekhawat, S.S. 2013 Role Performance of Gram Panchayat Members in Agricultural DevelopmentProgrammes, Ind. Res. J. Ext. Edu. 13 (2). 